\title{
The biodiesel market and public policy: a comparative analysis of Argentina and Brazil
}

\author{
Georges Gérard Flexor, Karina Yoshie Martins Kato \\ and Marina Yesica Recalde
}

ABSTRACT

This article presents a comparative case study of the institutional aspects of policymaking and the impacts that this has had on the development of the biodiesel market in Argentina and Brazil. The study draws upon an analysis of the policymaking process and, based on the available statistical evidence, discusses how this has influenced the market's development. Its findings underscore the differences between the two countries' policy objectives. In Argentina, issues relating to the supply of petrodiesel have been a crucial factor, whereas, in Brazil, the promotion of family farming has been a major objective. In Brazil, Petrobras has played a significant role, but some of the country's policy objectives in this area have not been fully met. In Argentina, the external market continues to be the driving force behind this industry.

KEYWORDS

JEL CLASSIFICATION

AUTHORS
Biomass energy, diesel fuels, development policy, markets, agribusiness, comparative analysis, Argentina, Brazil

Q48, Q42, O54

Georges Gérard Flexor is an adjunct professor at the Multidisciplinary Institute of the Universidade Federal Rural do Rio de Janeiro (ufrrJ), Postgraduate Social Sciences Programme in Development, Agriculture and Society (CPDA)/(ufrRJ), National Scientific and Technological Institute in Public Policy, Strategy and Development (INCT/PPED).gflexor@gmail.com

Karina Yoshie Martins Kato is a doctoral candidate in the Postgraduate Social Sciences Programme in Development, Agriculture and Society of the Universidade Federal Rural do Rio de Janeiro (UfRRJ) anirakato@yahoo.com

Marina Yesica Recalde is a post-doctoral researcher with the National Council of Scientific and Technical Research (CONICET) and the Department of Economics of the National University of the South (UNs). mrecalde@uns.edu.ar 


\section{I}

\section{Introduction}

Although biodiesel was first produced in the late nineteenth century, its production has been rapidly gaining ground in recent decades, and the debate about the issue has heated up in the last few years as a result of a number of different factors.

This article will discuss the biodiesel development policies of Argentina and Brazil. Both of these countries have been pursuing policies aimed at promoting biodiesel production and are positioning themselves as world-class producers and consumers. It is the authors' hope that this study will shed light on how a country's institutional structure influences the development of biofuel promotion policies and their outcomes. The conclusions reached in this regard can serve as a valuable diagnostic tool for use in the design of energy policies in countries dealing with similar sets of circumstances. They may also contribute to an understanding of how these two countries are positioned within the global energy system as it transitions towards more renewable sources of energy.

The methodology used in this analysis is based on comparisons of the motivations that originally drove these policies, the policymaking processes themselves and the results achieved in terms of the promotion of biodiesel in Argentina and Brazil. ${ }^{1}$ The study is composed of this introduction and four other sections. Section II outlines the underlying structure of the comparative analysis of biodiesel promotion policies in the two countries. Section III provides a description of the initial sets of circumstances and the importance of the driving factors in each case. This discussion points up the existence of two main policy drivers: the incentives provided by external markets, which have played a very important role in the case of Argentina, and the political agendas of the executive branch in Brazil. The focus then shifts to the policymaking process as such in each of these countries and to the driving forces and the various stakeholders that have been actively involved in promoting their interests within the institutional structure. Section IV covers the basic provisions of the laws and policy tools used to promote biodiesel production. The description of the policymaking process and the policy tools adopted in each country serves to underscore the important part played by institutions and stakeholders in the design of policies on biodiesel fuels. Within this context, emphasis is placed on the endogenous factors involved in policy design. The various repercussions of the introduction of promotional laws are analysed, along with their objectives in each case. This section also explores the consequences of these policies in terms of production and distribution. Section V offers some concluding observations within a comparative framework.

\section{II}

\section{Component factors in an analysis of the development of the biodiesel market}

The results produced by different countries' public policies for the promotion of biodiesel fuels are determined, in large part, by their policy objectives and their particular circumstances, but the political and institutional factors

$\square$ This study was conducted as part of the Postgraduate Social Sciences Programme in Development, Agriculture and Society (CPDA)/(UFRRJ) under a cooperation agreement between the Department of Economics of the National University of the South (UNS) and CPDA/UFRRJ.

1 The variables proposed in this study include trends in the consumption of petrodiesel, the percentage of total energy consumption in the transport sector accounted for by this fuel, trends in the production of soybeans as a biodiesel feedstock, trends in each country's biodiesel at work at the time that such policies are designed are the most influential elements of all. It is therefore of critical importance to determine what factors have been taken into account in assessing the different biodiesel development

exports, family farms' share in the production of biodiesel inputs and the concentration of land ownership. The information sources used included the databases of the Energy-Economic Information System (SIEE)/Latin American Energy Organization (OLADE), the National Petroleum, Natural Gas and Biofuels Agency (ANP), the Ministry of Agricultural Development and the World Bank, as well as information from the Ministry of Mines and Energy of Brazil and the Secretariat of Energy of Argentina. 
paths. An understanding of these considerations is essential to the discussion presented here.

Figure 1 provides a schematic outline of the different clusters of factors that have to be taken into account when analysing the development of biofuel promotion policies and their performance. As shown, the direction taken by the design of biofuel policies is directly influenced by a set of exogenous factors. At the same time, there is a two-way impact between a country's institutional structure and these policies, since the former determines the types of instruments used to promote biofuels, and, later on, once these policies are in place, they also exert an influence on the institutional structure. Finally, the cluster of factors relating to policy outcomes relate to the impacts that the policies have had on the various factors that they were designed to target directly, as well as on other sets of circumstances that they have influenced indirectly. Since the policymaking process is a dynamic one, this last cluster will also influence subsequent policymaking through a feedback loop.

FIGURE 1

Analytical clusters

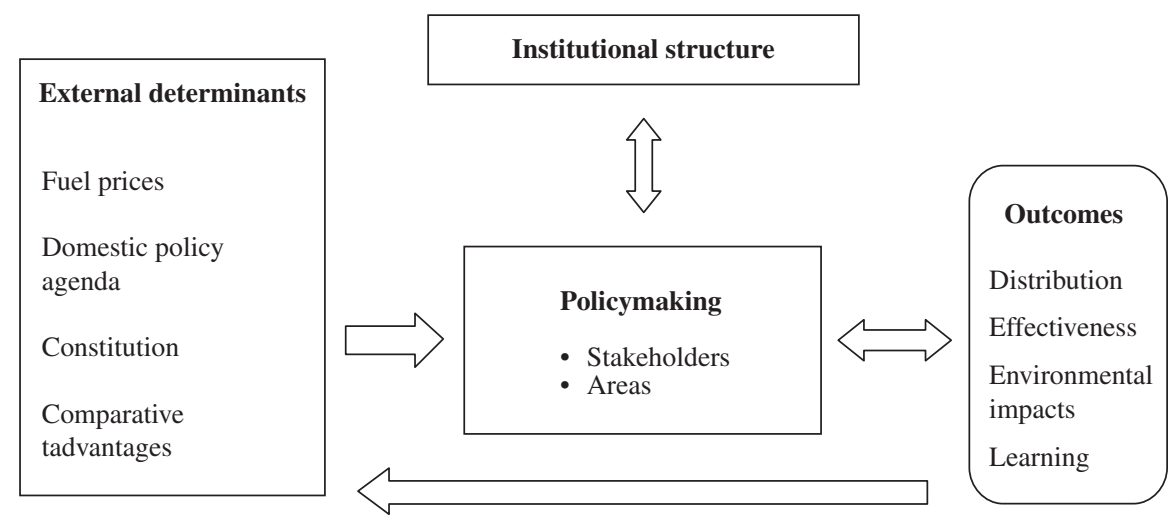

Source: Prepared by the authors.

The main reasons why countries have decided to promote biodiesel have varied from case to case. Some of the principal ones have to do with energy-related concerns, such as energy security, geopolitical independence and the impact of oil price volatility (Khanna, Scheffran and Zilberman, 2006). Environmental considerations involved in the effort to reduce greenhouse gas emissions is another driver of biofuel development. Biodiesel promotion policies in the European Union, for example, were in part triggered by public interest in reducing greenhouse gas emissions (Bureau and others, 2006; Timilsina and Shrestha, 2011). The opportunities that biodiesel production opens up for the agricultural sector (job creation, the use of state-of-the-art technology, and the marketing of biodiesel inputs and products) have also been a fundamental consideration (Pistonesi and others, 2008). In addition, for developing countries having a comparative advantage in the production of natural-resource-intensive goods, biofuels offer a strategic niche in the international economy (Msangi, Ewing and Rosegrant, 2006).
The interaction of these motivating factors gives rise to what might be characterized as the external determinants of biofuel promotion policies. This also endows the analysis with a multidimensional focus that encompasses political/institutional, agricultural, energy-sector, social and other impacts. This is why policies designed to boost biofuel development generally combine a number of different energy, agricultural, trade and environmental policy tools (Galperín and Pérez Llana, 2009).

Today, given the volatility of energy and raw materials markets, these considerations are prompting countries to step up their implementation of public policies designed to pave the way for the development of this energy source. The results of each of these policies largely depends on what the policy objectives are and on the different sets of circumstances existing in the countries concerned, but some of the most influential factors of all are the political and institutional structures and systems that are in place at the time that the policy is being formulated. The hypothesis advanced in this study is that institutional 
features are just as influential as external factors are in determining the sectoral trajectories or development paths of the biofuel industry. In other words, we maintain that the politics of policies ${ }^{2}$ has to be integrated into the analysis of biofuel promotion initiatives.

The differing development paths of the biodiesel industry in different countries, which are an outcome of the energy policies they implement, will give rise to differing results in terms of production and distribution. The institutional structure underlying biofuel promotion generates incentives and constraints that will influence investment decisions and, hence, production levels. The role played by the institutional structure is especially important when there are no established markets and when there is uncertainty about the future of energy markets and about what kinds of economically viable opportunities may open up. But the analysis must also take policies' undesired effects into account. In particular, because of the interaction between biofuel and agricultural produce markets, biodiesel promotion policies have an impact on food prices and on oilseed (biodiesel feedstock) production chains. The distributional effects are another core consideration in policy analysis, since examining the effects of a given policy entails determining who gets what. In other words, the institutional structure has differing effects on the costs and benefits of the persons and groups involved, since it affords rights or benefits to some economic agents that may represent additional (or increased) costs for others. The creation of different incentives will give rise to a group of "winners" and a group of "losers" that will derive different policy-generated benefits or be subject to different policy-generated costs.

\section{III}

\section{External determinants of biodiesel development}

While, globally, a variety of reasons underlie governments' decisions to introduce biodiesel promotion policies, at a more local level, the cases of Argentina and Brazil exhibit a number of similarities and differences.

In Argentina, the development of the biodiesel market has been driven mainly by external demand, and the chief factors prompting the introduction of policy incentives have originated in the energy sector, agricultural sector and agribusiness. In Brazil, the main driving force for the development of the biodiesel industry has been more directly related to the social policy agenda of President Luiz Inácio ("Lula") da Silva ${ }^{3}$ and only tangentially to energy-related considerations.

\section{The role of energy markets}

Since mid-2004, Argentina has been grappling with energy shortages which have recently been further exacerbated

\footnotetext{
2 Interest in the "politics of policies" has been growing over the last decade. With the development of today's new institutional economy and new political economy, the literature on the policymaking process has highlighted the importance of the role played by institutions in comparative policy performance. For an exploration of how this applies to the situation in Latin America, see IDB (2006).

3 Luis Inácio ("Lula") da Silva, of the Workers Party, was President of Brazil from 1 January 2003 to 1 January 2011. He was succeeded by Dilma Rouseff, also of the Workers Party.
}

by other factors. First of all, its primary energy matrix is heavily skewed towards hydrocarbons $(87 \%$ of domestic supply in 2009), and 58\% of its electricity matrix is composed of thermal energy. Second, its production levels are steadily declining, with year-on-year decreases, according to the Argentine Energy Institute (IAE), of $18 \%$ for petroleum and $6 \%$ for natural gas. Third, its reserves are shrinking, as attested to by a steady reduction in production horizons and limited refining capacity (Recalde, 2011a). The decline in reserves is graphed out in figure 2, which illustrates the trend in natural gas and petroleum reserves (NGRES and PRES, respectively) and in the reserves horizon - calculated on the basis of existing reserves and production levels - of natural gas (HNG) and petroleum (HP), which is a measurement of the number of years that existing reserves will last at the current level of output. This shortened horizon is the result of the depletion of oil and natural gas wells, ${ }^{4}$ along with decreasing investment in exploration, which began in the early 1990s following the deregulation and privatization of oil and gas fields. This situation has been

\footnotetext{
4 This may change in the wake of the discovery of large petroleum and natural gas fields in unconventional geological formations in 2010 and 2011. The scale of those deposits and the economic viability of tapping into them have not yet been assessed, however.
} 
FIGURE 2

\section{Argentina: Hydrocarbon reserves and horizons, 1970-2008}

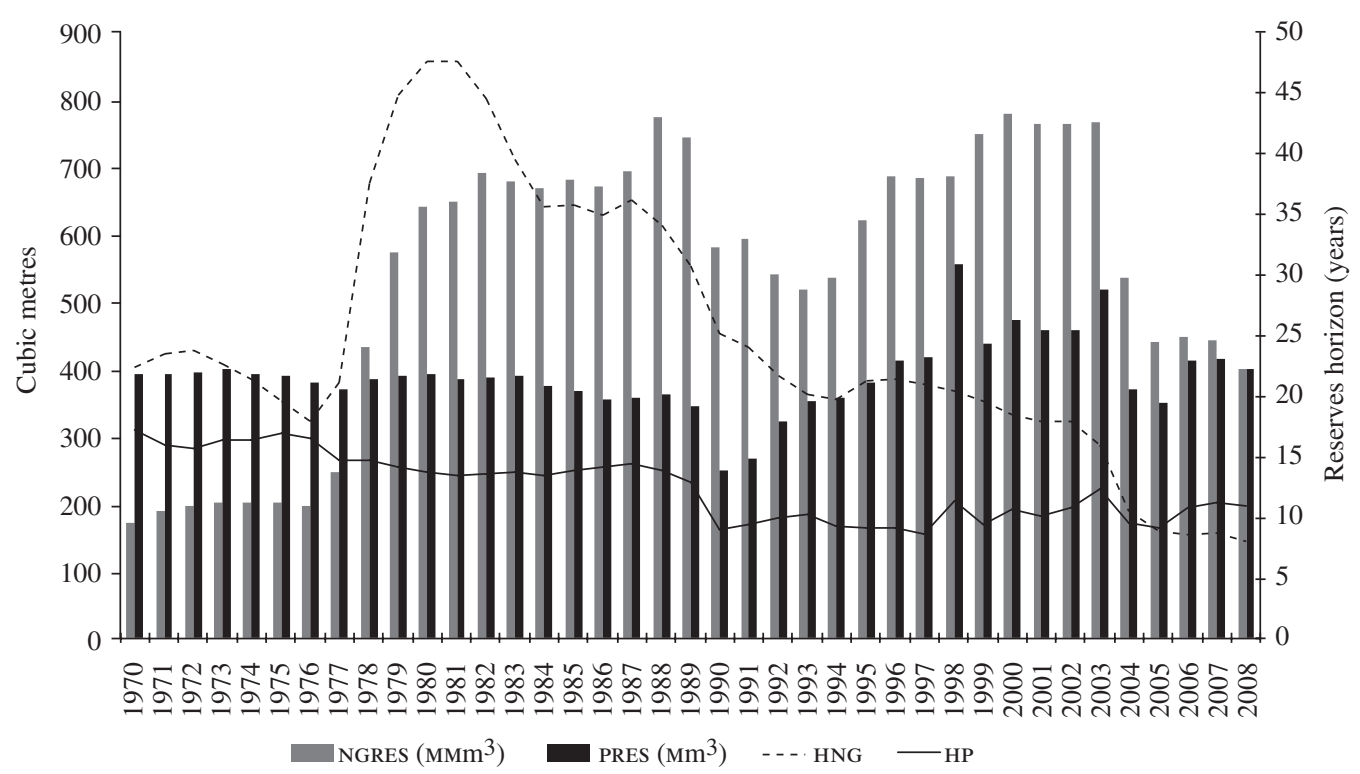

Source: M. Recalde, Sistemas energéticos, mercado y Estado. El rol de los recursos naturales energéticos y la política energética en el caso argentino, Madrid, Editorial Académica Española, 2011.

aggravated in recent years by the reaction to the price distortions created by the introduction of Decrees Nos. 310/2002 and 809/2002 and Decision No. 337/2004 of the Ministry of Economic Affairs and Production (Recalde, 2012). ${ }^{5}$

The promotion of biodiesel in Argentina is linked to the importance of petrodiesel, which accounts for nearly $50 \%$ of derivative fuel consumption and is the main fuel used in the transport and agricultural sectors (40\% and $96 \%$, respectively, of fuel consumption in 2009). ${ }^{6}$ According to Chidiak and Stanley (2009) and Recalde (2010), the supply of this fuel is limited because, in addition to the depletion of existing wells, as mentioned earlier, the country has no more idle refining capacity. Although, since 2010-2011, there has been a comparable deterioration in the situation with regard to both petrodiesel and gasoline, so far the situation in terms of imports has been more serious in the case of

\footnotetext{
5 For an in-depth discussion of trends in production, reserves and investment in exploration and their determinants, see Recalde (2011b and 2011c).

6 Calculated on the basis of statistics obtained from the energy database of the Secretariat of Energy, available at: http:energía.mecon.gov.ar
}

petrodiesel ${ }^{7}$ than it has been for gasoline, partly because of the increasing use of diesel as a fuel for motor vehicles.

In Brazil, unlike in Argentina, energy-related issues, while certainly a factor, are not the most important consideration. Brazil has been producing and using biofuels since the 1970s, when it began to produce bioethanol from sugar cane as a means of promoting renewable fuels. Furthermore, the discovery of large oil fields off the Brazilian coast (known as the "pre-salt" reserves) has altered the energy supply paradigm. These reserves are estimated at between 70 million and 100 million barrels of oil equivalent and have put Brazil on the geopolitical petroleum-production map while at the same time sharply reducing the risk of oil shortages.

Brazil's energy sector is not driven by general supply problems. The country has a clean energy mix

\footnotetext{
7 According to information from the Energy Secretariat, imports of petrodiesel, measured in United States dollars, have been climbing since 2002 (although they dipped in 2009 as a direct result of the slump in fuel demand triggered by the economic crisis that began in mid-2007), while the output of local refineries has exhibited a yearon-year decrease (the growth rates for petrodiesel output have been $7.62 \%$ in $2005 / 2006 ; 2.64 \%$ in $2006 / 2007 ;-3.43 \%$ in $2007 / 2008$; and $-3.96 \%$ in $2008 / 2009$ ).
} 
that includes a large proportion of biofuels. Its energy inventory indicates that, as of 2009, $47.3 \%$ of domestic supply came from renewable sources $(15.2 \%$ ethanol and sugar-cane derivatives, $15.2 \%$ hydroelectricity, $10 \%$ firewood and $3.8 \%$ other renewable energy sources, including biodiesel). Another consideration is that, for Brazil, continuing to have a clean energy mix is a strategic tool in its bid to consolidate its diplomatic ambitions. The promotion of biofuels is a means of signalling Brazil's commitment to the global energy agenda and to environmental issues, which could also be linked to the fact that Brazil's transport sector has higher carbon dioxide $\left(\mathrm{CO}_{2}\right)$ emissions levels than its Argentine counterpart (see figure 3 ).

Figure 4 illustrates the fact that petrodiesel is used more in Argentina while the use of gasoline is more prevalent in Brazil. This fact, coupled with the downswing in local petrodiesel production, demonstrates why the energy sector has been one of the main drivers behind the promotion of biodiesel in Argentina.

\section{The agricultural sector as a driving force}

The agricultural sector has played a central role in driving the promotion of biodiesel in Argentina, but it has been a much less influential factor in Brazil. In Argentina, more than $95 \%$ of the raw material used to produce biodiesel comes from soybeans. Soybeans are the largest single oilseed crop that Argentina produces, and the land area devoted to it has been soaring in the past few years. Most of the harvest - whether in the form of soybeans or soy oil - is exported. In 2006-2009, over half these exports went to China, the world's largest market for soybean oil. Since 2009, however, when China took a strategic decision to set up plants in its own territory and to begin processing soybeans there, Argentine exports of soybean oil have fallen. ${ }^{8}$ Given this downturn in external demand, the creation of a local biodiesel market represents a new business opportunity for oilseed producers and refineries. Nonetheless, one of the unexpected results of biodiesel production in Argentina is that the external market, ${ }^{9}$ rather than the domestic market, quickly became one of the major driving forces behind its development (CADER, 2010).

8 For the first quarter of 2011, Argentina recorded a $39.7 \%$ yearon-year drop in its exports of soybean oil.

9 Argentina has gone from being the seventh-largest producer of biodiesel in 2007 to being the world's second-largest producer (with $13.1 \%$ of the market), after the United States (with 14.3\%) (ECLAC, 2011).
In Brazil, on the other hand, the agricultural considerations that spurred the introduction of policies to promote the development of biodiesel are more varied and less directly related to soybean production. The aim of helping small-scale farmers and their families to play a more active role in society has been a major motivation for the promotion of biodiesel in Brazil since Luiz Inácio "Lula" da Silva was elected president in late 2002. And this was also one of the main reasons for the institutionalization of the National Biodiesel Programme in $2005 .{ }^{10}$ It was also hoped that the programme would boost the production of castor oil, which is sited primarily in north-eastern Brazil, a poor and arid region, although the importance of soybean oil as an input for the production of biodiesel is not disputed, since soybeans are the only oilseed that is being produced on a big enough scale to make it a cost-competitive and reliable source of supply for the market. The emergence of the biodiesel market opened up an attractive business opportunity by paving the way for the creation of a domestic market that can boost domestic demand for oilseeds, which in turn can provide greater stability and security for the producers of the country's hefty supply of soybean oil.

\section{Promotional instruments and their design}

Argentina first began to take active steps to promote biodiesel in 2001, when Decree No. 1396/2001 was issued. That decree sets out a plan for making biodiesel production competitive, states that its production is in the national interest and introduces a number of economic tools for promoting its use. The effort to promote biodiesel really started to come into its own, however, in 2004, when energy supply problems began to become apparent. That was the year in which the Secretariat of Agriculture, Livestock, Fisheries and Foodstuffs launched the National Biofuels Programme (Decision No. 1156/2004), one of whose main objectives was to backstop rural sectors and provide them with advisory assistance in setting up biodiesel and bioethanol plants as an alternative to local soybean and soybean oil production. In May 2006, Argentina passed Act No. 26.093, entitled "Regulation

\footnotetext{
10 According to studies conducted by the Ministry of Agricultural Development, Ministry of Agriculture, Livestock and Supply, the Ministry of National Integration and the Ministry of Urban Affairs, for every $1 \%$ of diesel oil that is replaced with biodiesel produced using raw materials provided by family farms, 45,000 jobs can be created in the rural sector that would provide wages averaging US\$3,000 to each worker. Family farms create 1 job for every 10 hectares of farmland, whereas agribusinesses create 1 job for every 100 hectares (Lima, 2005).
} 
FIGURE 3

Argentina and Brazil: $\mathrm{CO}_{2}$ emissions of the transport sector

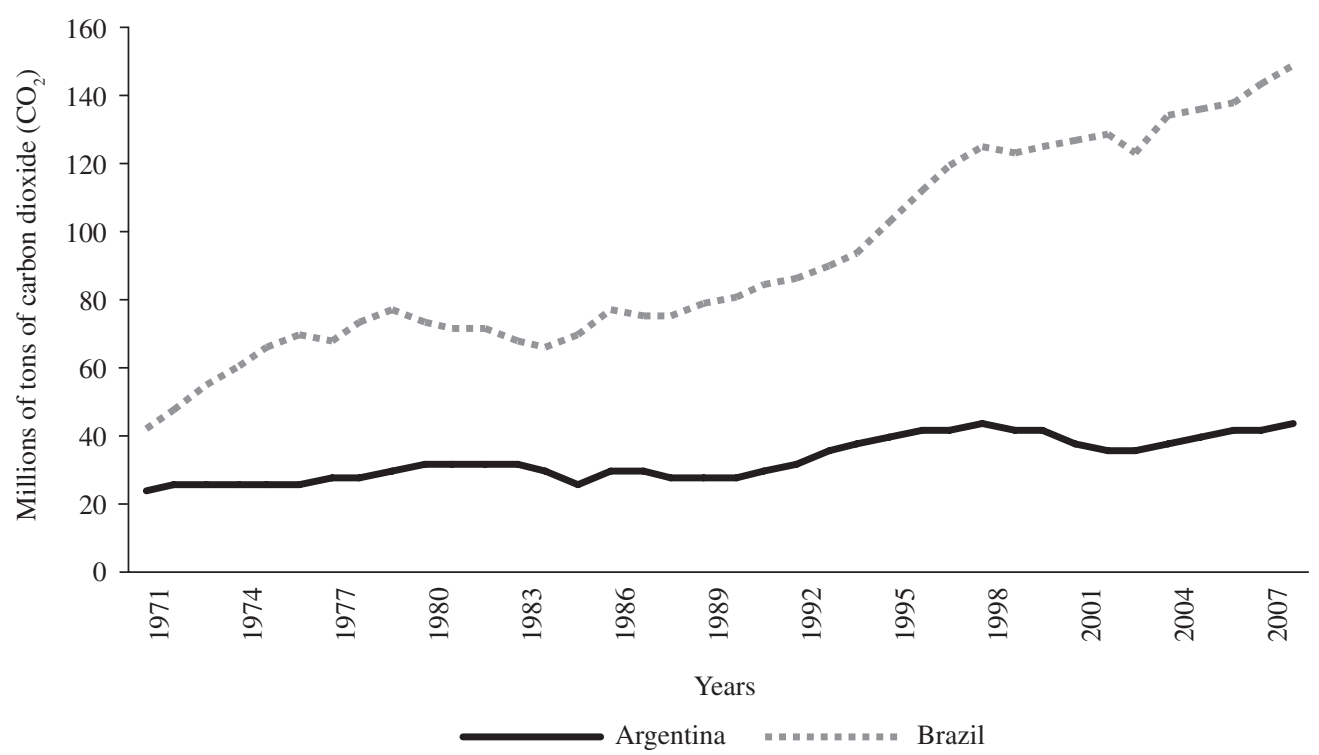

Source: Prepared by the authors on the basis of the official United Nations database.

FIGURE 4

Argentina and Brazil: Shares of different fuels in the transport sector, 2008 (Percentages)

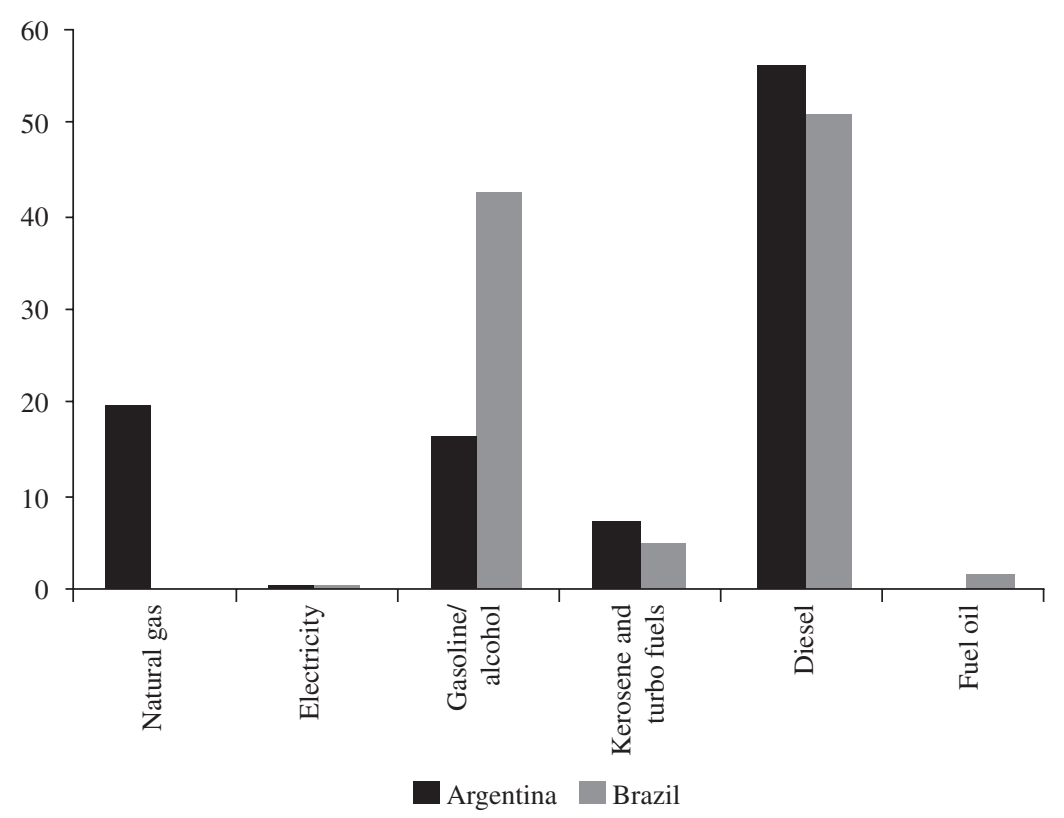

Source: Prepared by the authors on the basis of figures from the database of the Latin American Energy Organization (OLADE)/Energy-Economic Information System. 
and Promotion of the Sustainable Production and Use of Biofuels" (along with implementing regulations set forth in Decree No. 109/2007), which establishes the legal framework for biofuels production. ${ }^{11}$

With respect to design issues, Chidiak and Stanley (2009) point out flaws in the regulatory instruments in this area, especially as regards coordination between public and private stakeholders and even within various subdivisions of the public sector owing to the divergent interests of the parties concerned. Within the public sector, this was reflected in the differing views of the Ministry of Economic Affairs and Public Finance, the National Institute for Industrial Technology (INTI) and the National Institute for Agricultural Technology (INTA) or the Ministry of Agriculture, Livestock and Fisheries. In the private sector, pressure groups associated with the first two links in the biodiesel production chain include the Argentine Biofuels and Hydrogen Association (AAHB), the Argentine Agrarian Federation (FAA) and the Argentine Biofuels Chamber (CARBIO) and various groups of the public.

One of the controversial issues that arose had to do with the types of economic incentives being offered and their potential impact on national accounts. The stakeholders most at odds with each other were groups in the agricultural sector and in the Ministry of Economic Affairs. ${ }^{12}$ The Ministry was focusing on tax revenues: as of 2004, fuel taxes were accounting for $5.5 \%$ of total tax receipts, taxes on soya exports for $12 \%$ and the value-added tax (VAT) for $30 \%$.

Another amendment made to the bill provided for the inclusion of federal provincial bodies and private agencies in the National Biofuels Sustainable Production and Use Advisory Committee and gave the Committee the authority to set benchmark prices. The authority to implement these provisions has been delegated to the Secretariat of Energy of the Ministry of Federal Planning, Public Investment and Service, which is to be assisted in this task by the National Advisory Committee (created

11 The bill was submitted to the Senate on 6 July 2004. One of its provisions, which was subsequently deleted, stated that any company, including oil companies, could qualify for the benefits provided for therein. The law that was ultimately passed, however, states that the incentives are primarily intended for small and medium-sized enterprises (SMEs).

12 The bill originally provided for an exemption from the tax on petrodiesel $(20.2 \%)$ and the infrastructure tax $(\$ 0.05$ per litre of petrol). The Ministry came back with a counter-offer of a tax rebate on biofuel sales, accelerated amortization of production plants' profits and exemptions from the duty on imported inputs and from the minimum presumed income tax. by virtue of article 3 of Act No. 26.093)..$^{13}$ Specifications of the quality standards to be met by the $\mathrm{B} 100^{14}$ that is then mixed with diesel were established in 2010 by Decision No. 6/2010 and were later modified by Decision No. 828/2010. In July 2010, Decision No. 554/2010 raised the compulsory diesel blending rate from $5 \%$ to $7 \%$, and the government appears to be working its way towards a further increase in the mandatory cut to $10 \%$, which would help to curb the country's rising imports of petrodiesel and diesel oil. Biodiesel plants are bound to provide producers in the domestic supply chain (who can avail themselves of the incentives provided for in the new law) with sufficient quantities of biodiesel to comply with the $5 \%$ cut and to make supplies available to blending plants.

Unlike Argentina, Brazil has a great deal of experience in the promotion of renewable energy, especially biofuels. In the 1970s, in response to the international oil crisis and a severe local foreign-exchange shortage and as a means of reducing its reliance on petroleum, Brazil launched a renewable energy incentive policy. As part of that policy, it established Pró-Álcool, a national programme designed to boost the production of ethanol from sugar cane. Biodiesel, however, did not begin to figure on the energy policy agenda until the late 1990 s or early 2000 s.

As a first step, the federal government set up inter-agency committees that included representatives of government ministries, universities and research centres. ${ }^{15}$ During this stage, energy and environmental issues, together with agricultural interests in the business community, were the main driving forces behind the effort. ${ }^{16}$ When President da Silva took office in late 2002,

13 This Committee includes representatives of the Secretariat of Energy, the Secretariat of Agriculture, Livestock, Fisheries and Foodstuffs, the Secretariat for the Environment and Sustainable Development, the Ministry of Finance, the Secretariat of Industry, Trade and Small and Medium-Sized Enterprises, the Ministry of Science, Technology and Productive Innovation and the Federal Public Revenue Administration. 14 The term "biodiesel" is used to refer to the pure form of this fuel (B100), which has been designated as an alternative fuel by the Department of Energy and the Department of Transportation of the United States. B100 can be used in its pure form but it is more often used as an additive to conventional diesel fuel.

15 One of the initiatives that provided a framework for this process was the National Biodiesel Production Programme (ProBiodiesel), which was launched in 2002 and coordinated by the Ministry of Science and Technology. More than 200 specialists and organizations belonging to the Brazilian Biodiesel Technology Network were involved in its design.

16 The programme's objectives were: (i) to reduce the country's reliance on petroleum products; (ii) to create new markets for oilseeds, particularly soybeans; (iii) to boost overall demand for alternative fuels; and (iv) to cut carbon dioxide emissions. 
however, the National Biodiesel Production Programme (ProBiodiesel) was completely revamped, and social goals in line with the new Administration's founding principles became an important element.

In 2003 an inter-ministerial working group was set up, and responsibility for administering the country's biodiesel policy was transferred from the Ministry of Science and Technology to the Executive Office. ${ }^{17}$ Following the publication of the working group's report, biodiesel was introduced into the country's energy mix with the launch of the National Biodiesel Programme in December 2004.

The three pillars of the National Biodiesel Programme are social inclusion (with family farming being used as a vehicle for its promotion), environmental sustainability and economic viability. Under this programme, biodiesel use became compulsory, with a mandatory cut for diesel being set at 2\% between 2008 and 2012 and rising to 5\% thereafter. The implementation of the biodiesel policy called for a number of institutional changes, one of which was a name change for the National Petroleum Agency, which became the National Petroleum, Natural Gas and Biofuels Agency (ANP).

The biodiesel market is being consolidated with the help of ANP-administered public tenders, in which firms that have what is known as a social fuel stamp (sCS) enjoy preferential conditions, and a system for certifying industries that use inputs produced by family farms. The tenders are a way of ensuring that the benchmarks set by the National Biodiesel Programme are achieved. Petrobras has played a central role in this programme, since it is the sole buyer and is chiefly responsible - along with the Alberto Pasqualini Refinery (REFAP), which is also controlled by Petrobras - for ensuring that legally mandated blending ratios are complied with.

The National Biodiesel Programme uses a variety of promotional devices, including the institutionalization of tenders (price guarantees), a differentiated tax regime (designed to foster social inclusion) and mandatory blending ratios (in order to make sure that there is a market for biodiesel).

\section{- Policy tools}

As mentioned earlier, many countries around the world are developing policies to promote biofuels production. There are a variety of policy tools that can be used for this purpose, either singly or in combination with one another, depending on the policy objectives

17 The Executive Office is headed by the President's Chief of Staff. being pursued and circumstances in the country concerned. The choice of tools will depend on a number of factors that need to be evaluated. Some of the main financial incentives are tax cuts (for investment, credits, differential capital amortization schemes) and lending instruments (the establishment of clear-cut lending mechanisms, reductions in implicit investment risk, guarantees designed to improve access to bank financing, low-interest loans). Argentina and Brazil have used different combinations of these policy tools to create their individual promotional policy packages. Tables 1 and 2 outline the different promotional schemes in use in these two countries.

Both Argentina and Brazil use a combination of quantitative and price-based policy tools. The former include a compulsory blending ratio, which ensures that producers will have a domestic market for their output. The latter comprise a mix of tax and financial benefits.

In Argentina, article 13 of Act No. 26.096 delineates the eligibility requirements for the promotional benefits set forth in that law, which can be met by industrial ventures located in the country that produce biofuels for the domestic market as their sole business activity -i.e., firms in which the State has a majority interest or agricultural producers (which have to prove that at least $50 \%$ of their assets are located in Argentina). In addition to the price-based and quantitative policy criteria established in the law and its accompanying regulatory decrees, there are also quality standards for biofuels in general and for biodiesel in particular. The law also clearly states that companies must have the necessary equipment in their plants to take the measurements needed to determine compliance with those quality standards.

These promotional tools aside, many authors have asserted that one of the factors driving biodiesel production recently has been the differentiated tax rates applying to exports of soybeans, oil and biodiesel. The export tax is levied at a rate of approximately $35 \%$ for soybeans, $32 \%$ for oil and just $20 \%$ for biodiesel. As a result, it has been one of the main drivers for production.

Finally, an alternative use for biodiesel is being explored by the Secretariat of Energy, which in 2009 launched the Renewable Energy Generation Programme (GENREN). Under this programme, blocks of $150 \mathrm{MW}$ are put out to tender for electricity generating projects that use biofuels. Official information provided by Energía Argentina S.A. (ENARSA) indicates that the prices assigned to the selected biofuel-fired thermal generation projects range from US\$ 258 to US\$ 297 per MWh. 


\section{Argentina: biodiesel promotional pricing tools}

\begin{tabular}{|c|c|c|c|c|c|c|}
\hline \multicolumn{7}{|c|}{ Type of tool } \\
\hline \multirow[b]{2}{*}{ Legal instruments } & $\begin{array}{l}\text { Quantitative } \\
\text { requirements }\end{array}$ & \multicolumn{5}{|c|}{ Financial incentives } \\
\hline & Quotas & VAT & Profits tax & Liquid fuels tax & Infrastructure tax & $\begin{array}{l}\text { Tax on transfers } \\
\text { or imports of } \\
\text { petrodiesel }\end{array}$ \\
\hline Act No. 26.096 & $5 \%$ & $\begin{array}{l}\text { Rebate of the percentage } \\
\text { corresponding to } \\
\text { capital goods and/or } \\
\text { infrastructure works }\end{array}$ & $\begin{array}{l}\text { Accelerated } \\
\text { amortization }\end{array}$ & $\begin{array}{l}\text { Exemption for } \\
\text { the percentage of } \\
\text { biofuel in the mix }\end{array}$ & $\begin{array}{l}\text { Exemption for } \\
\text { the percentage of } \\
\text { biofuel in the mix }\end{array}$ & $\begin{array}{l}\text { Exemption for } \\
\text { the percentage of } \\
\text { biofuel in the mix }\end{array}$ \\
\hline Decision No. 554/2010 & $7 \%$ & & & & & \\
\hline \multicolumn{7}{|c|}{ Qualitative requirements } \\
\hline $\begin{array}{l}\text { Decision No. 6/2010 and } \\
\text { Decision No. } 828 / 2010\end{array}$ & \multicolumn{6}{|c|}{ Quality specifications for biofuels to be blended with X percentage of petrodiesel. } \\
\hline GENREN & \multicolumn{6}{|c|}{$\begin{array}{l}\text { Public tender to cover } 150 \mathrm{MW} \text { of biofuel-fired thermal generation for energy for sale on the wholesale electrical } \\
\text { power market. } \\
\text { Guaranteed } 15 \text {-year purchase contracts at pre-set price. }\end{array}$} \\
\hline
\end{tabular}

Source: Prepared by the authors on the basis of Act No. 26.096 and the corresponding implementing regulations.

GENREN: Renewable Energy Generation Programme.

TABLE 2

\section{Brazil: biodiesel promotional pricing tools}

\begin{tabular}{|c|c|c|c|c|}
\hline Federal taxes & $\begin{array}{l}\text { Family farming, north, } \\
\text { north-east and semi-arid }\end{array}$ & Family farming in general & $\begin{array}{l}\text { General rule (other } \\
\text { types of agriculture) }\end{array}$ & Diesel oil \\
\hline $\mathrm{IPI}^{\mathrm{a}}$ & - & - & - & - \\
\hline $\mathrm{CIDE}^{\mathrm{b}}$ & None & None & None & $\mathrm{R} \$ 0.07$ \\
\hline PIS/PASEP and COFINS ${ }^{c}$ & Reduction of up to $100 \%$ & Reduction of up to $68 \%$ & $\begin{array}{l}\mathrm{R} \$ 0.22 \text { (equal to or less } \\
\text { than rate applying to diesel } \\
\text { oil in all cases) }\end{array}$ & $\mathrm{R} \$ 0.148$ \\
\hline Total (per litre) & $R \$ 0.00$ & $R \$ 0.07$ & $R \$ 0.218$ & $R \$ 0.218$ \\
\hline
\end{tabular}

Source: Prepared by the authors on the basis of Decree No. 5.297 (6/12/2004), Decree No. 5.298 (6/12/2004) and Directive No. 1 of the Ministry of Agricultural Development, 19 February 2009.

\footnotetext{
a Tax on manufactures.

b Economic domain tax.

c Social integration tax and social security contributions.
}

As noted earlier, the most innovative feature of Brazil's programme is its use of tenders in which the acceptable price levels differ according to whether the bidding projects are promoting family farming or not. Thus, social inclusion has been promoted by designing a tax scheme that benefits business activities that patronize family farming and the semi-arid and northern regions, whose human development indices have traditionally been lower than those of the rest of the country. In order to do this, a system was designed based on a "social fuels stamp" in order to distinguish among different categories of farmers, regions and raw materials; ratings are then issued on the basis of a combination of these factors. The social fuels stamp is a certificate issued by the 
Ministry of Agrarian Development to producers that buy their inputs from family farms. ${ }^{18}$ Some of the benefits available to producers that hold this certificate are access to special credit lines from the National Economic and Social Development Bank (BNDES) ${ }^{19}$ and preferential access to some of the lines of credit provided under the

18 The social fuels stamp system was overhauled in February 2009 following a debate between representatives of the family-based agricultural sector and representatives of the oil processing industry and biodiesel producers. As a result, the percentages set for the purchase of raw materials from family farms was set at $15 \%$ for the northern and central-western regions and at $30 \%$ for the south, south-east, north-east and semi-arid regions.

19 In 2010, its name was changed to the Development Bank of Brazil (BNDES).
National Family Agriculture Programme (PRONAF) for farmers who plant oilseed crops.

The percentage set for the blending ratio is one of the main tools for the promotion of biodiesel. The controversy here is between groups hoping to see rapid market growth (the agricultural and industrial segments of the market) and those advocating a moderate growth rate that will allow for the inclusion of small farmers. The initial cut was set at $2 \%$, but it was raised to $3 \%$ in July 2008, to 4\% in January 2009 and to 5\% in April 2010.20

20 Since 2010, ANP has also been looking at the possibility of making the use of biodiesel compulsory in maritime transport. Advocates of the idea of increasing the cut are proposing that the compulsory blending level be set at $10 \%$.

\section{IV \\ Promotion policies: current status and potential effects}

Table 3 provides a comparative overview of external factors, policymaking features and some of the main outcomes of this process. In the following sections we will analyse the current situation and the potential implications for each of the sectors affected by these policies. It is important to make it clear that, given the very short time horizon involved in evaluating these policies, some of the observed results may not be a direct effect of the implementation of these policies but may instead be attributable to external factors. This is especially the case in Argentina, where external demand has been the main factor driving biofuel production.

\section{The current situation in the energy sector}

As noted earlier, Argentina's fuel imports went from accounting for $4.84 \%$ of its total imports in 2004 to $7.78 \%$ in 2010 . As shown in figure 5 , since 2005 , the production of petrodiesel and diesel oil have been separated from local production, and imports have obviously had to rise since then. Because these policies have been in place for so short a time, official statistics on their results are not yet available. The Ministry of Planning estimates, however, that the compulsory $7 \%$ cut in petrodiesel will boost annual consumption of biodiesel in the domestic market from 750,000 tons/year to 1.05 million tons/ year, which is roughly equal to the level of Argentina's current annual imports of petrodiesel. If this turns out to be the case, these policies may well prove to have been successful in reaching their energy objectives.

By the same token, in Brazil diesel imports account for a significant percentage of total imports, although here, unlike in Argentina, domestic production of diesel is also on the rise. In 2010, Brazil imported nearly 9 billion litres of fuel, with the main driving force being the growth of domestic consumption. As figure 6 shows, with the expansion of diesel production and the introduction of the compulsory blending ratio, imports have levelled off. Senatore and others (2010) assert that Brazil managed to save US\$ 2.84 billion worth of diesel imports between 2005 and 2010 by increasing domestic diesel production and substituting biodiesel for petrodiesel.

\section{The current situation in the agricultural sector and the biodiesel production chain}

Argentina's biodiesel production capacity soared from 130,000 to 2.5 million tons between 2006 and 2010 . Unlike the situation in Brazil, however, this increase in installed capacity was not solely a result of regulatory initiatives, since, while $51 \%$ of output is going to exports, $43 \%$ is being taken up on the domestic market. The sector has a formidable production capacity, with an average of 110,000 tons per plant, and there are at least five 


\title{
Argentina and Brazil: a comparison
}

\begin{tabular}{|c|c|c|c|}
\hline & External factors (drivers) & Policymaking (stakeholders, rules, scenarios) & Outcomes (distribution, allocation) \\
\hline Argentina & $\begin{array}{l}\text { - Growing energy deficit: increasing } \\
\text { imports of diesel oil owing to limited } \\
\text { supply capacity. } \\
\text { - Drop in demand from China. } \\
\text { - Pressure from the main supply-chain } \\
\text { stakeholders. } \\
\text { - External market for biodiesel driving } \\
\text { the industry more than the local } \\
\text { market. }\end{array}$ & $\begin{array}{l}\text { - Main pressure groups involved: the } \\
\text { State, via the Secretariat for Energy and } \\
\text { Public Finance; Ministry of Economic } \\
\text { Affairs; National Institute for Agricultural } \\
\text { Technology (INTA); Argentine Biofuels } \\
\text { and Hydrogen Association (AAHB); } \\
\text { Argentine Agrarian Federation (FAA) and } \\
\text { Argentine Biofuels Chamber (CARBIO). } \\
\text { - Special policy tools: compulsory blending } \\
\text { ratio of 7\%; various tax exemptions; } \\
\text { GENREN tenders. }\end{array}$ & $\begin{array}{l}\text { - Very large production capacity. } \\
\text { - Appropriation of profits by main } \\
\text { agents in the soya production } \\
\text { chain: large soybean oil producers. } \\
\text { - Integration of the soya production } \\
\text { chain. } \\
\text { - Concentration of production } \\
\text { capacity. } \\
\text { - Effects on the concentration of } \\
\text { land used for soybean crops. }\end{array}$ \\
\hline Brazil & $\begin{array}{l}\text { - Agenda of President Lula (social } \\
\text { inclusion) and presidential } \\
\text { environmental agenda (National } \\
\text { Biodiesel Programme). } \\
\text { - Petroleum and diesel prices } \\
\text { (imported by Brazil). } \\
\text { - Past successes with biofuels policies } \\
\text { (path dependence). }\end{array}$ & $\begin{array}{l}\text { - Main pressure groups involved: the } \\
\text { State via Petrobras; biodiesel producers' } \\
\text { association; automotive industry; fuel } \\
\text { industry; family farming institutions } \\
\text { (ministry, trade unions, social } \\
\text { movements). } \\
\text { - Special policy tools: social fuel stamp, } \\
\text { ANP public tenders, compulsory blending } \\
\text { ratio of 5\% (2012), cuts in the PIS/PASEP } \\
\text { and coFINS taxes. }{ }^{\text {a }} \\
\text { - Distribution of decision-making power } \\
\text { (Ministry of Mines and Energy, ANP). }\end{array}$ & $\begin{array}{l}\text { - Large production capacity, } \\
\text { although smaller than Argentina's. } \\
\text { - Appropriation of profits by soya } \\
\text { production chain. } \\
\text { - Benefits for soya-producing } \\
\text { regions (south and central-west). } \\
\text { - Active role for Petrobras in } \\
\text { meeting social goals. }\end{array}$ \\
\hline
\end{tabular}

Source: Prepared by the authors.

GENREN: Renewable Energy Generation Programme.

a Social taxes.

FIGURE 5

\author{
Argentina: consumption, production and imports \\ of diesel oil and petrodiesel, 2000-2009 \\ (Thousands of cubic metres)
}

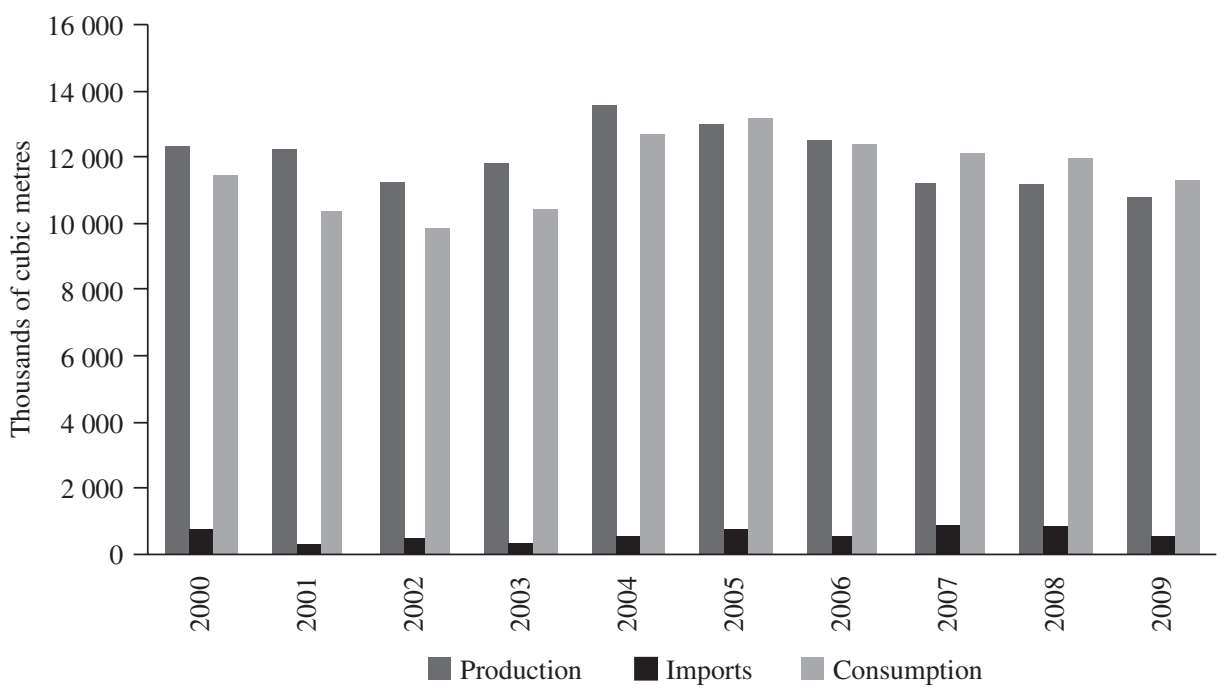

Source: Prepared by the authors on the basis of figures from the Secretariat of Energy and Public Finance. 
FIGURE 6

Brazil: consumption, production and imports of diesel, 2004-2009

(Thousands of cubic metres)

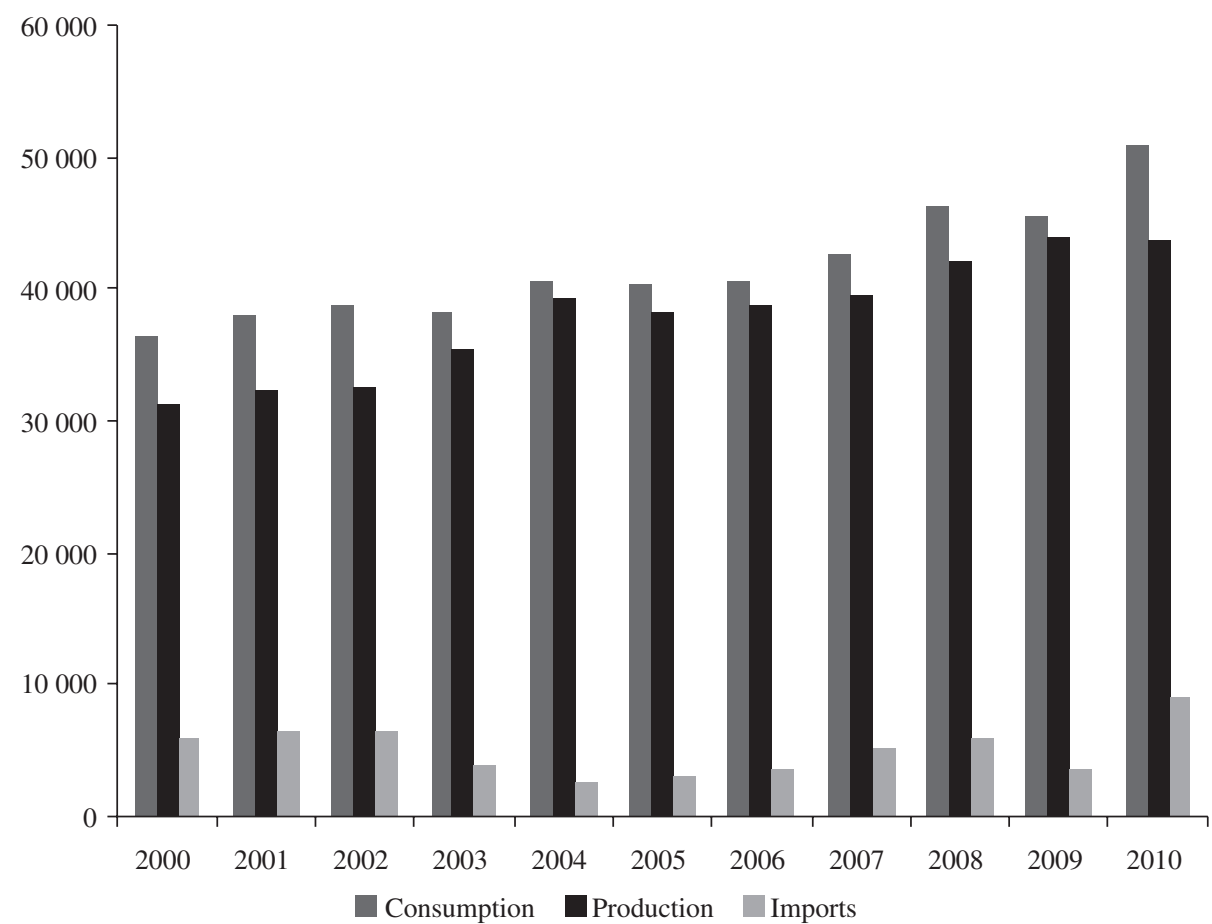

Source: Ministry of Mines and Energy, Balanço energético nacional 2010, Brasilia, 2010.

large plants with a production capacity of over 250,000 tons that export more than $75 \%$ of their output. These producers are not eligible for the incentives provided by these new laws, which target production for the domestic market. These laws have therefore not had any significant effect on the development of the market other than in terms of small-scale producers, which account for $6 \%$ of installed capacity and sell $100 \%$ of their output on the domestic market.

Biodiesel production gives soy producers a chance to expand their marketing channels as well as their earning opportunities all along the chain, which is why many of them are involved in manufacturing it as well. The impact that the increase in biodiesel production has had on soybean production can be gauged by looking at the increase in the output of this oilseed, which represented $88 \%$ of the harvested land area in 2008-2009, as shown in figure 7. However, trends in soybean production have been linked to trends in the external market, and the largest share of that market is accounted for by the export of soy meal. According to the National Institute of Statistics and Censuses (INDEC), ${ }^{21}$ between 2007 and 2009 the exports of the soya production complex amounted to nearly US\$ 15 billion and accounted for $24 \%$ of total exports.

In Brazil, on the other hand, the launch of the National Biodiesel Programme jump-started local biodiesel production almost as soon as it was introduced. In just five years, the programme spurred the creation of an industrial complex capable of producing over 5 billion litres of biodiesel per year. With the compulsory $5 \%$ fuel blend generating a demand for an estimated 2.5 billion litres, there appears to be no threat of a supply shortage in the near future, and plants have idle capacity. Unlike the situation in Argentina, nearly all the country's biodiesel output is sold on the domestic market; firms rarely export a portion of what they produce..$^{22}$

21 Available at: www.indec.gov.ar

22 The biodiesel industry in Argentina exhibits a relatively high degree of concentration. Nearly $60 \%$ of production capacity is accounted for by just 10 firms. 
FIGURE 7

Argentina: land under cultivation and soybean output, 1970-2010

(Millions of hectares)

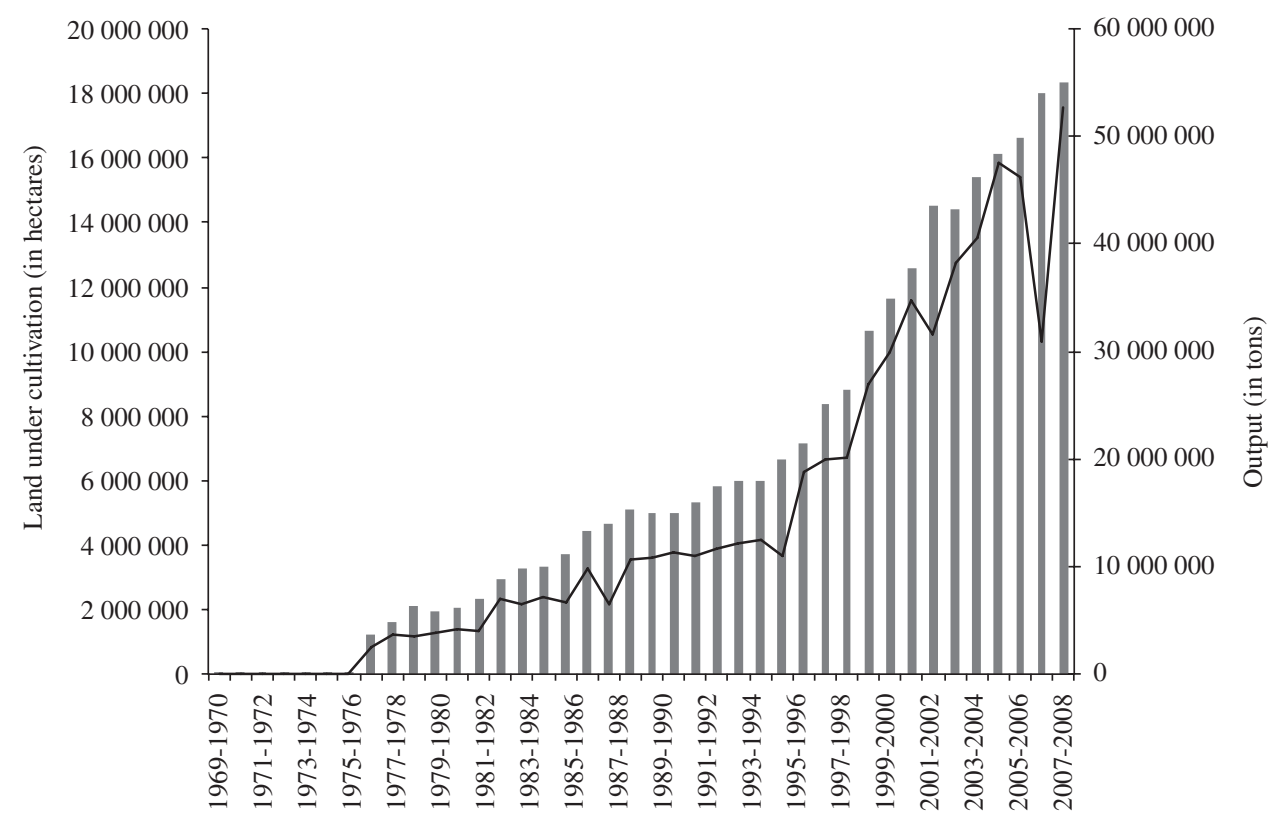

Amount of land, nationwide, planted with soybeans (in hectares), by year

- Nationwide soybean output (in tons), by year

Source: Prepared by the authors on the basis of figures from the Ministry of Agriculture, Livestock and Fisheries.

With the growth of the biodiesel market, producers are looking for a way to integrate the industry and gain greater control over the chain by becoming the leading players in the production of the main feedstock — soybeans — and, in some cases, beef tallow as well. Transnationals such as the Archer Daniels Midland Company and Cargill are entering the market, and the average size of processing plants is on the rise, with capacity climbing from 64,000 litres per year in 2008 to 75,000 litres per year as of May 2010. On average, plants are smaller in Brazil than they are in Argentina, however. Nonetheless, Brazilian plants, too, have increased in number and production capacity during this period, with the number of plants having a capacity of over 150,000 litres rising from six to nine and those with a capacity of over 300,000 litres increasing from one to three.

\section{Social considerations and the impact on distribution}

The distributional effects of the expansion of biodiesel production in Argentina can be analysed by looking at its impact on the agricultural sector. One of the first distributional effects of this industry's growth has been the crowding out of small-scale producers, who, with the entry of large-scale investors and rising land prices, have decided to rent out their land and have ceased to operate as producers. This has, in turn, had an impact on rural employment (Giarraca and Teubal, 2005; Honty and Gudynas, 2007; Biodiversidad, 2007). According to the estimates made by a number of authors, mechanization and the introduction of genetically modified soybeans led to the displacement of at least 200,000 small-scale producers between 1990 and 2001 as producers strove to lower biodiesel production costs so that biodiesel would be more competitive. Data provided by ECLAC (2011) and Botta and Selis (2003) indicate that mechanization and the direct planting method used in Argentina have cut person/hour requirements so much that four out of every five jobs have been lost.

In Brazil, despite the government's efforts to promote family farming, most of the soybeans used in biodiesel production are supplied by large-scale producers. This clearly has strong implications in terms 
of the government's social and environmental goals. More than $90 \%$ of biodiesel is produced from soybeans or beef tallow. It may be that as little as $20 \%$ of the country's biodiesel output is produced by family-based agricultural enterprises, and the feedstock for $90 \%$ of that is small-scale farmers' soybean crops, chiefly in the southern and central-western regions of the country. Unfortunately, these farmers are not among the poorest segments of the farm population, which are the target groups for the National Biodiesel Programme.

The number of agricultural producers in the biodiesel chain is growing, however, largely because of the entry of the three Petrobras plants and the creation of Petrobras Biocombustivel (PBio), which is the largest buyer of oilseeds from family farms in the semi-arid regions of north-eastern Brazil.

One especially important factor, however, is that the hope of attaining the social and environmental goals underpinning the National Biodiesel Programme hinges, to a great extent, on how well PBio runs its operations and manages their financial and logistical aspects. PBio has enough political clout and enough financial and human resources at its command to enable it to shoulder part of the corresponding supply-chain costs, to promote family farming and to make headway towards the achievement of the social and environmental goals of Brazil's biodiesel policy.

Groups with links to family-based agriculture have voiced concern about the effectiveness of these new policy tools, however. In their view, the inclusion of family farming in this production sector is far from assured, and there is a high risk that this policy will operate along the lines of the traditional model of integration for family farming and agro-industry. These groups advocate a more decentralized production model in which family farmers are given more support by business enterprises and the State so that, in the long run, they can transition towards the production of vegetable oils instead of oilseeds (see figure 8).

FIGURE 8

Brazil: number of family-based feedstock suppliers, 2005-2010

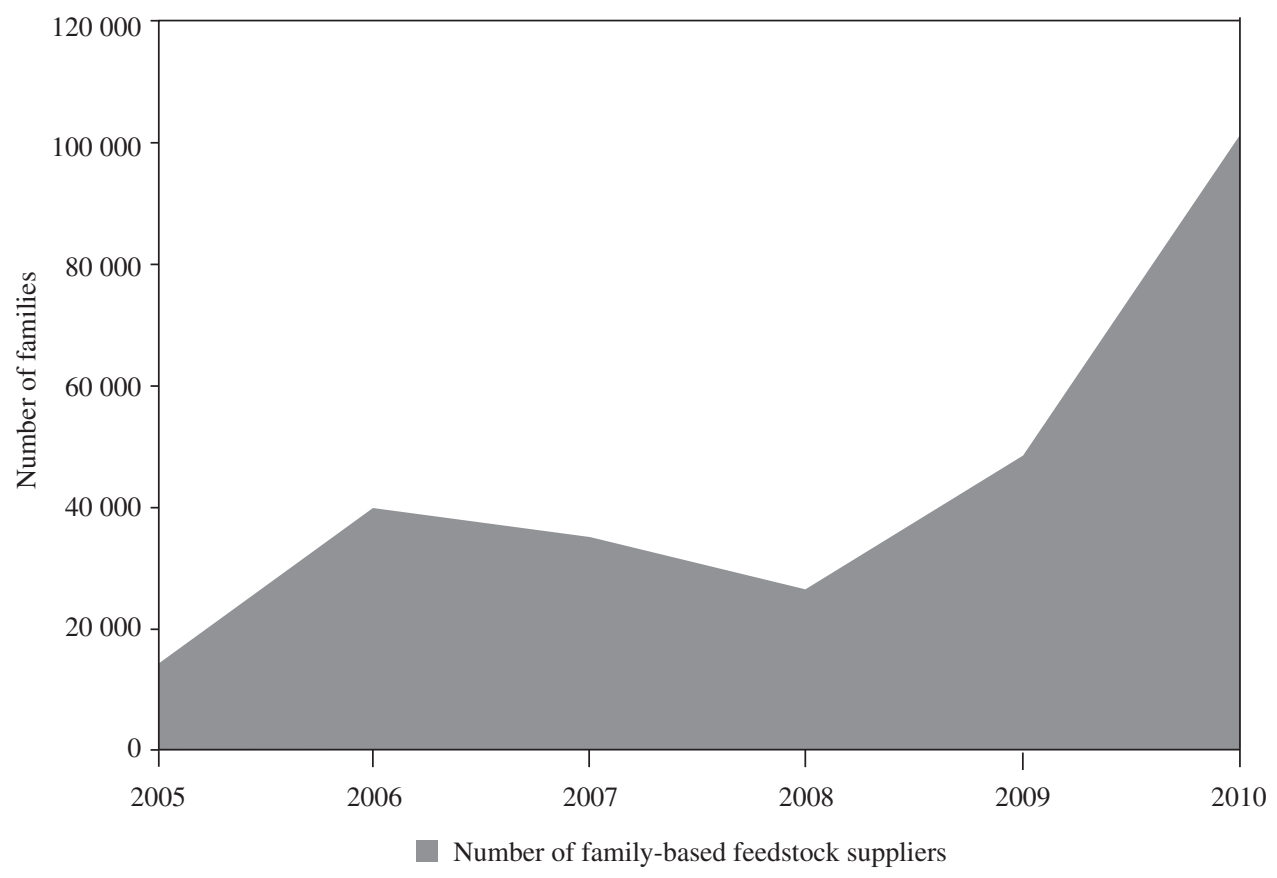

Source: Prepared by the authors on the basis of Ministry of Agricultural Development and G.M. Senatore and others, "O biodiesel e sua contribuição ao desenvolvimento brasileiro", Fundación Getulio Vargas and União Brasileira do Biodiesel, October 2010 [online] http://www. ubrabio.com.br/sites/1700/1729/00000201.pdf 


\section{V}

\section{Conclusions}

Any comparative case study of Argentina and Brazil must be based on a recognition of the two countries' different political and economic circumstances and the different driving forces behind the move to regulate their biodiesel industries. In both cases, production incentive policies were introduced in the early 2000s, but since then the development paths of their biodiesel markets have diverged in a number of ways.

In Argentina, the main motivation has been the need to find a way for the energy sector to supply more of the country's energy requirements. Since 2004 the energy sector has been in crisis, and the situation has been exacerbated in recent years as hydrocarbon reserves and refining capacity shrink. The need to curb the country's growing imports of petrodiesel has been one of the factors behind the increase in the compulsory blending ratio from $5 \%$ to $7 \%$, which seemed very likely to be raised to $10 \%$ by the end of 2012 and even to $20 \%$ for some sectors, such as passenger transportation or the agricultural sector. Petrodiesel imports have been boosted in recent years by growing demand from the electricity sector, which has no idle capacity left and is encountering serious problems in securing a sufficient supply of natural gas, its main fuel. Biodiesel can help this sector by making it possible to build biofuel-fired generating plants, especially now that the GENREN programme and other electrical power supply programmes are under way. ${ }^{23}$

Agricultural interests underlie these energy-related drivers. In the 2009/2010 harvest, the country produced nearly 54.5 million tons of soybeans. The interests of this sector are shown up quite clearly by an analysis of

23 One such programme is the Energy Plus Programme launched in 2006 pursuant to Decision No. 1281/2006. Various analysts of the Argentine energy industry contend that this programme forces largescale users to negotiate the purchase of the supply needed to cover the increase in their electrical power demand relative to a benchmark level (set at their 2005 consumption levels) while at the same time creating an additional business opportunity for potential producers. As provided for in the corresponding decision, the supply for the Energy Plus Service is provided by the added generating capacity of generators, co-generators and self-generators that is not traded on the wholesale electrical power market, does not come from existing generating plants or is not linked into the wholesale electrical power market. Thus, the new investments in the Energy Plus Service have to be negotiated by large-scale users and suppliers, which can enter into contracts whose terms, conditions and prices are determined by the private parties concerned. its role in the design of energy policy, the creation of more attractive tax incentives and the entry of some of the major soybean producers into biodiesel production.

In Brazil, on the other hand, the policy on biodiesel production has gained momentum since 2000 , and the country's previous experiences played a decisive role when the plan for promoting this industry was being drawn up. The Pró-Álcool Programme has been a major success from an energy standpoint, but a failure in social policy terms, and that is why social objectives were explicitly incorporated into Brazil's policy on biodiesel. This policy has also opened up an opportunity for civil society organizations to take part in the debate surrounding energy policy, which had previously focused entirely on technical issues.

Since so little time has passed since these policies were introduced, their results cannot yet be fully evaluated. Nonetheless, certain differences can already be identified on an a priori basis. Data from official sources appear to indicate that Argentina's energy matrix is transitioning towards an increased substitution of biofuels for diesel oil and petrodiesel, and to some extent its biodiesel incentive policy can therefore be considered a success. However, biofuel production in Argentina is overwhelmingly geared to the external market, and the export sector - composed of large business groups - is not the policy's target group, which is not benefiting from the incentives. Thus, the expansion of the country's biodiesel production capacity is more directly a result of the growth of the world soy market and Argentina's tax scheme for exports of soy products, which has made biodiesel more attractive than soybeans or soybean oil. The Argentine biodiesel market can therefore be divided into two groups: largescale soybean oil producers catering to the international market, which have turned Argentina into the world's largest biodiesel exporter, and small-scale producers whose output is sold on the domestic market as a means of meeting compulsory blending targets.

Accordingly, the stated policy objective of promoting small-scale ventures does not appear to have been achieved. One of the possible reasons for the presence of large industrial enterprises and the emphasis on exports could be that the legislated economic incentives fall short of what is needed. With distorted fuel prices in effect and fairly low export taxes on biofuels, the 
production of biodiesel for export is the most profitable option for producers.

In Brazil, on the other hand, the driving force behind the biodiesel market's growth has been the domestic market, with the pace of growth being determined by the State via the National Energy Policy Council (CNPE). The creation of domestic market guarantees and tax incentives has prompted large-scale biodiesel and soybean producers to take part in government-sponsored tenders and to turn towards the domestic market. Thus, the policy tools used have been successful in ensuring supply and averting shortages in the domestic market. Brazil has also apparently managed to reduce petrodiesel imports, thereby fulfilling one of the programme's other objectives.

Family farms are involved to a very limited extent in the National Biodiesel Programme, however, and soybeans are the main feedstock used for the production of biodiesel. Recent experience shows that structural shortcomings in the country's family-based agricultural sector ${ }^{24}$ that hinder access to resources, technology and capital are limiting the programme's effectiveness.

In Brazil, PBio is one of the two main forces behind the effort to attain the social and environmental goals

24 Especially in north-eastern Brazil. of the National Biodiesel Programme. This company's status as a joint public/private venture allows it to pursue social goals in line with Brazil's energy policy and the federal government's priorities, in addition to its purely private business objectives.

The clear-cut differences between Argentina's and Brazil's success in achieving their programmes' goals have to do with the maturity of their energy policies, their experience and, above all, the existence in Brazil of a firm like Petrobras, which the State can use to implement and guide the steps taken to pursue its energy policy objectives. This has not been the case in Argentina. However, in early 2012 the Argentine government decided to resume control over the country's largest energy company, YPF S.A., ${ }^{25}$ which had been privatized some 20 years earlier. Its use of this corporation as a vehicle for the implementation of its energy policy could do away with the differences between the two countries' policy development paths and the scope of their policy objectives.

25 In accordance with Act No. 26.741, which was published in the Boletín Oficial of 7 May 2012, and the implementing regulations set out in Decree No. 660/2012, the ownership structure of YPF S.A. is such that $26 \%$ belongs to the State and $25 \%$ to the corresponding states, with the rest being divided up between national and international investors that buy shares in the company on the stock market. See: www.infoleg.gov.ar
ANP (National Agency of Petroleum, Natural Gas and Biofuels) (2011), Boletim mensal de biodiesel, Rio de Janeiro.

Biodiversidad (2007), No. 52, April [online] http://www.grain.org/ biodiversidad/?type $=47 \& 1=0$.

Botta, G. and D. Selis (2003), "Diagnóstico sobre el impacto producido por la adopción de la técnica de siembra directa sobre el empleo rural. Una Recopilación. Brasil. Lei $\mathrm{N}^{\circ} 11.116$ de 18 de maio de 2005".

Bureau, J.C. and others (2006), "European biofuel policy: how far will public support go?", Handbook of Bioenergy Economics and Policy, M. Khanna and others (orgs.), Springer.

CADER (Argentine Biofuels Chamber) (2010), Estado de la industria argentina de biocombustibles. Comienza el mercado nacional de biodiesel y bioetanol, Buenos Aires, May.

Chidiak, M. and L. Stanley (2009), "Tablero de comando para la promoción de los biocombustibles en Argentina", Projects documents, No. 242 (LC/W.242-P), Santiago, Chile, February.

ECLAC (Economic Commission for Latin America and the Caribbean) (2011), "Estudio regional sobre economía de los biocombustibles 2010: Temas clave para los países de América Latina y el Caribe", Discussion Paper, Santiago, Chile, March.

EPE (Empresa de Pesquisa Energética) (2010), Balanço energético nacional 2010: ano base 2009, Rio de Janeiro.
Galperín, C. and C. Pérez Llana (2009), "Desarrollo de los biocombustibles, interrelación de políticas y opciones de política comercial”, Revista Argentina de Economía Agraria, vol. 11, No. 1, Buenos Aires, Asociación Argentina de Economía Agraria.

Giarraca, N. and M. Teubal (2005), El campo argentino en la encrucijada. Estrategias y resistencias sociales, ecos en la ciudad, Buenos Aires, Alianza Editorial.

Honty, G. and E. Gudynas (2007), Agrocombustibles y desarrollo sostenible en América Latina y el Caribe. Situación, desafíos y opciones de acción, Montevideo, Latin American Centre of Social Ecology (CLAEs)/Development, Economy, Ecology, Equit - Latin America (D3E).

IDB (Inter-American Development Bank) (2006), The Politics of Policies. Economic and Social Progress in Latin America: 2006 Report, Washington, D.C.

Khanna, M., J. Scheffran and D. Zilberman (2006), "Bioenergy economics and policy: introduction and overview", Handbook of Bioenergy Economics and Policy, M. Khanna and others (orgs.), Springer.

Lima, P.C.R. (2005), Biodiesel: um novo combustível para o Brasil, Chamber of Deputies, Brasilia.

Ministry of Mines and Energy (2010), Balanço energético nacional, 2010, Brasilia.

(2006), Balanço energético nacional, 2006, Brasilia. 
Msangi, S., M. Ewing and M. Rosegrant (2006), "Biofuels and agricultural growth: challenges for developing agricultural economies and opportunities for investment", Handbook of Bioenergy Economics and Policy, M. Khanna and others (orgs.), Springer.

OLADE/ECLAC/GTZ (Latin American Energy Organization/Economic Commission for Latin America and the Caribbean/German Agency for Technical Cooperation) (2003), Energía y desarrollo sustentable en América Latina y el Caribe: Guía para la formulación de políticas energéticas (LC/G.2214-P), Santiago, Chile. United Nations publication, Sales No. S.03.II.G.160.

Pistonesi, H. and others (2008), "Aportes de los biocombustibles a la sustentabilidad del desarrollo en América Latina y el Caribe: Elementos para la formulación de políticas públicas", Project Documents, No. 178 (LC/W.178-P), Santiago, Chile, Economic Commission for Latin America and the Caribbean (ECLAC).

Recalde, M. (2012), "Los recursos energéticos en Argentina: Análisis de la renta", Problemas del desarrollo. Revista Latinoamericana de Economía, vol. 43, No. 170, Mexico City, National Autonomous University of Mexico. (2011a), "Energy policy and energy market performance: the Argentinean case", Energy Policy, vol. 39, No. 6, Amsterdam, Elsevier.

(2011b), Sistemas energéticos, mercado y Estado. El rol de los recursos naturales energéticos y la política energética en el caso argentino, Madrid, Editorial Académica Española.

(2011c), "Determinantes de la inversión en exploración de hidrocarburos: Un análisis del caso argentino", Cuadernos de Economía, vol. 34, No. 94, Madrid, Complutense University of Madrid, January-April.

(2010), "Sistemas energéticos y desarrollo socio económico: Implicancias del control sobre los recursos naturales energéticos", thesis, Bahía Blanca, Universidad Nacional del Sur.

Senatore, G.M. and others (2010), "O biodiesel e sua contribuição ao desenvolvimento brasileiro", Getulio Vargas Foundation/União Brasileira do Biodiesel, October [online] http://www.ubrabio. com.br/sites/1700/1729/00000201.pdf.

Timilsina, G.R. and A. Shrestha (2011), "How much hope should we have for biofuels?", Energy, vol. 36, No. 4, Amsterdam, Elsevier. 